\title{
Vulnerable Situations in the Classroom
}

\author{
Ina ter Avest \\ VU University Amsterdam/independent researcher 'Z-in-gesprek'
}

Kontakt: khteravest@gmail.com

eingereicht: 29.1.2021; überarbeitet: 20.3.2021; angenommen: 25.3.2021

\begin{abstract}
Zusammenfassung: Die Covid-19-Pandemie konfrontiert uns mit der Verletzlichkeit unserer Gesundheit, aber nicht weniger wichtig ist die Verletzlichkeit unseres psychischen Wohlbefindens. In diesem Beitrag untersuche ich die mögliche(n) Stärke(n) der Verletzlichkeit - von Personen und Religion(en). Zunächst stelle ich die Arbeit der Theologin Caroline Gustavsson vor, die zwischen „erlebter Vulnerabilität“, „erzählter Vulnerabilität“ und „induzierter Vulnerabilität" unterscheidet. Als Beispiele und zur Illustration dieser Konzepte konzentriere ich mich auf die Stimmen von Grundschülern, Sekundarschülern und einer Religionslehrerin. Im Religionsunterricht wird erklärt, dass Religion(en) verletzlich ist/sind, weil es keinen „Beweis“ dafür gibt, dass Gott existiert, oder umgekehrt, dass die biblischen Erzählungen von „reellen“ Dingen handeln. Indem man an die Erfahrungen junger Menschen anknüpft und aktuelle Ausdrucksformen und Metaphern verwendet, kann sich die Verletzlichkeit - von Personen, von Religion(en) - in eine Stärke verwandeln.
\end{abstract}

Schlagwörter: Verletzlichkeit, Vulnerabilität, Bildung, Religion, Religionsunterricht

Abstract: The Covid-19 pandemic confronts us with the vulnerability of our health, but no less important is the vulnerability of our psychological well-being. In this contribution I explore the possible strength(s) of vulnerability - of persons and religion(s). First, I introduce the work of the theologian Caroline Gustavsson who distinguishes between: "experienced vulnerability," "narrated vulnerability" and "induced vulnerability". As examples and illustrations of these concepts, I focus on the voices of primary school pupils, secondary school pupils and a RE teacher. In RE classes it is stated that religion(s) is/are vulnerable because there is no 'proof' that God exists, or conversely that scriptural narratives are about 'real' things. By touching upon experiences of young people, using current-day expressions and metaphors, the vulnerability - of persons, of religion(s) - can turn into a strength.

Keywords: vulnerability, education, religion, RE classes

\section{Introduction}

Vulnerability is definitely the most striking feature of all that 'Covid-19' confronts us with. To begin with, the pandemic confronts us with the vulnerability of our health, but no less important is the vulnerability of our psychological well-being. In this contribution I focus in particular on vulnerability in education - the vulnerability of pupils and teachers. The December issue of Narthex 20(4), a Dutch professional journal for Life Orientation and Education, was devoted to 'vulnerable issues'. This special issue served as a source of inspiration for my contribution. The question I explore in this contribution is: How do we understand 'vulnerability' and in what way can vulnerability be part of a pedagogical strategy?

First of all, I draw on the expertise of the theologian Caroline Gustavsson, regarding her interpretation of the concept of vulnerability in general, and in the specific case of the classroom.

Secondly, I listen to the experiences of a number of secondary school students who talk about their feelings of vulnerability: in what context they feel vulnerable, and how they deal with such feelings of vulnerability. I focus on two pupils in particular: Erhan in group 8 of primary school (on his way to secondary school) and Gianny in the first year of secondary school. 
Thirdly, the vulnerability of a teacher, Maria, reveals itself in the unexpected situation of a lesson that was prepared down to the last detail. As a teacher she presents us with a case study, a situation in which she unexpectedly found herself in a vulnerable position and was left speechless.

After familiarising the reader with these experiences of vulnerability in the day-to-day practice of education, I give the floor to Jan Marten Praamsma, who speaks about 'vulnerable religion'.

Finally, by way of close reading, I look with some distance at what a number of pupils wrote and showed, and at the role which memory played in the next part of teacher's Maria's lesson. Vulnerability can turn into strength, is one of the (provisional) conclusions. ${ }^{1}$

\section{Dissecting the Concept of Vulnerability}

In her contribution to 'Facing the Unknown Future' (2020)2, the theologian Caroline Gustavsson identifies vulnerability as an important quality of education. Her starting point lies in Brené Brown's thinking on vulnerability. According to Brown, 'uncertainty', 'risk' and 'being exposed to emotions' are the characteristics of vulnerability (Gustavsson, 2020a, p. 185 ff.; Gustavsson, 2020b, p. 35). Vulnerability is not a sign of weakness; on the contrary, precisely a lack of vulnerability is a sign of weakness, Brown holds (Brown, 2012).

Vulnerability is at the core of sincere openness - an openness that can only be shown in an atmosphere of mutual trust. Important is that the story you are sharing has been processed by you to some extent, so that you can show your vulnerability on the basis of a certain strength. Fresh wounds, according to Brown (2010), first need to be processed and worked through before it can be shown how vulnerable the wound, and how unruly and imperfect the process of healing of it, was. In order to possess the capacity to face the pain and sorrow, to process them and subsequently show them, a sense of self-worth is important. Only on the basis of self-worth can a person cope with the uncertainty and the risk, and deal with talking about the accompanying emotions, without being overwhelmed by them.

Gustavsson articulates the concept of vulnerability in three aspects, which she names as follows: "experienced vulnerability," "narrated vulnerability" and "induced vulnerability". An inequality in position (a teacher in relation to her pupils) and an 'experienced vulnerability' that has not yet been sufficiently processed, can lead to uncomfortable situations. Uncomfortable situations can also arise when the narrator is not (yet) in control of her own feelings of 'experienced vulnerability'. This occurs in the classroom when Erhan tells his story, as we will see below. 'Narrated vulnerability' is a story about a vulnerable situation; feelings that are put into words. Lastly, Gustavsson refers to 'induced vulnerability', by which she means a showing of vulnerability by the listener. In Erhan's class, both the classmates and the adults show their 'induced vulnerability'. Before you can show your vulnerability as a teacher, Gustavsson concludes, you need to do the work to reflect on your own experience and think carefully about what it is that you want to show, why you evaluate the classroom situation in this way at this moment, and how you want to show this. Vulnerability, Gustavsson says, can be a powerful quality of education, but sometimes it is not yet the right time, or the right moment. Gustavsson notes this herself, in remembering her primary school teacher who shared her experience of an encounter with an angel (Gustavsson, 2020a, p. 183), and in critically looking back on her own confessions to her first-year theology students, regarding her own vocation (Gustavsson, 2020a, p. 187).

\section{The Voice of the Pupils - Experienced Vulnerability}

In the fall of 2020, when Covid-19 had left a strong mark on Dutch education, and everyone had learned to make a virtue of the necessary Zoom classes, a written assignment was given to 15- and 16-year-old pupils. The selected pupils attended one of two forms of Dutch secondary education: higher general continued education or preparatory scientific education. The pupils were asked to write about the times they feel vulnerable (at home, school, etc.) and - in case they had an experience of getting hurt - to write about this. 150 pupils, boys and girls, responded.

The assignment was phrased as follows: "Tell about vulnerability in your own life." To get the pupils started, the following guiding questions were given:

\footnotetext{
${ }^{1}$ The author would like to thank Stijn van Tongerloo (MPhil) for the critical proofreading of this text.

${ }^{2}$ Her contribution is reproduced in abbreviated form - in Dutch - in the December issue of Narthex 20(4).
} 
- In what way might you be vulnerable - and maybe really feel vulnerable - at school, in relation to your classmates and your teachers?

- In what way might you be vulnerable - and maybe really feel vulnerable - at home?

- In what way might you be vulnerable in regard to the future?

- In what way might you be vulnerable - and maybe really feel vulnerable - in relation to your own inner feelings?

- Perhaps you have been hurt before, seriously or less seriously?

The assignment concluded with: "in that case / in those cases we wish you much strength to cope with it, and thank you for taking the time to write down your experiences and views on vulnerability."

A selection of these 150 stories was published in the December issue of Narthex 20(4), a professional journal for Life Orientation and Education.

Below, a number of the published answers of the pupils about vulnerability are quoted. In quoting, we refer to the guiding questions of the written assignment. The quotes provide a glimpse into the lives of 'vulnerable students'.

Although no specific question was asked about this, it turns out that for the pupils, social media are the 'place of vulnerability':

"Because people can voice their opinions about anything and anyone, without realising how much hurt they can cause someone. It's so easy to judge people when you're sitting behind your computer screen."

Having to perform at school is a source of vulnerability:

"The way I can be vulnerable at school is because some teachers or pupils tell you that you're not going to achieve anything in your life. And when you're being told that, it makes you pause and feel shy."

Vulnerability has to do with being humiliated:

"I don't feel well anymore when a teacher is around me, and I hate going to that class. That teacher told me, 'I feel sorry for your mother that you're her son.'"

Vulnerability is also about risk-taking:

"Vulnerability is doing something without knowing what will happen next. So, you're taking a risk. This can be: saying

'I love you' first. This can cause disappointment or grief."

The pupils not only talk about what makes them vulnerable, but also about how they deal with it:

"At home you can be vulnerable too, since your parents know everything about you. But generally speaking, you are not/less vulnerable at home, because there is a lot of love. People live together, because they love each other and by going through difficult things together, you 'beat' the vulnerability together and it turns into love."

Home, for some pupils, is not the place where vulnerability can be shown - which triggers vulnerability:

"At home I'm sometimes very vulnerable because my parents don't know how I feel. But they think they do. When I feel sad but still carry a smile, I have a moment of vulnerability."

It is mainly the painful side of vulnerability that has been described above. However, pupils also see the beauty of being vulnerable:

"I think that vulnerability makes a person warmer, softer and kinder. And that sharing your vulnerability is not weak at all, but brave. I try to be brave by sharing my vulnerability."

"You can also be vulnerable in a good way, for example when everyone is very positive about you and you're having fun with everyone. You can then be very happy and cheerful, and I think that's also a kind of vulnerability because you're overjoyed with everything and everyone. And you don't want it to stop."

Last but not least, Covid-19 makes pupils vulnerable, as one of them writes:

"What I'm most afraid of is the future. My mother is very vulnerable to diseases, and now that the coronavirus is here

I'm very scared. If my mother gets the coronavirus, there's a big chance that she will die. So I'm very vulnerable and afraid, but we keep our spirits up."

It is no accident that I started with a quote about social media, and ended with a quote about Covid-19. As influential as the Covid-19 period is for the school life of pupils, and as much as this year of lockdown will affect the rest of their school career - in a certain sense, school life also continues 'normally', with events like: a first declaration of love, worries about the future because of failing grades, and last but not least, the impact of social media, which should not be underestimated - an impact that is perhaps greater in this Covid-19 period than ever before.

\section{Erhan and Gianny - Induced Vulnerability}

In the fall of 2020, a seven-part documentary series called 'Classrooms' was released on Dutch television (Sylbing \& 
Gould, 2020). The documentary filmmakers Sarah Sylbing and Ester Gould followed the lives of 11- to 13-year-old pupils attending primary and secondary schools in Amsterdam-North, a so-called disadvantaged neighbourhood. The pupils were followed by the documentary makers from summer 2019 - summer 2020. In the series, we get to know pupils who await their final educational recommendation, which indicates the type of secondary education they will be able to attend, and secondary school pupils whose school trajectories have already been determined. The main theme of the series is 'unequal opportunities in education'.

In the third episode of the documentary series, teacher Thijs discusses his vulnerable pupils. These pupils are vulnerable because they grow up in situations where the rights of children are continually violated, i. e., rights as stipulated in the Convention on the Rights of the Child, especially Article 18 about the responsibility of educators, and the support that should be given to parents, and Article 28 about equal access to quality education. Teacher Thijs wants his pupils to be able to relax, to not have "to fight, to struggle for their existence." "These children spend a lot of time on the streets. And there, they only get opportunities to make the wrong choices. There's not a single person on the street who says: 'Hey, hey, you shouldn't do that!' But making quick money or carrying a gun, listening to music full of threatening language - that's easy." This is the world his pupils live in. One pupil in particular worries him: Gianny.

\section{I Tears}

Miss Astrid worries about her pupils as well. She brings up the topic of 'making the right choice' with her group 8 pupils (11- to 13-years-olds). For that lesson, she invites a neighbourhood policeman and an 'experience expert'. The neighbourhood policeman starts the conversation by referring to "those guys you sometimes see hanging around at the coffeeshop" (which is located next to the school) or at the Albert Heijn supermarket." He says: "You're now the oldest kids of the primary school - group 8. So you'll soon be going [to the next school] almost entirely on your own; you'll be stepping onto the big schoolyard, all on your own." Then the policeman turns to one of the pupils, Erhan: "Now imagine you're standing in that big schoolyard. Then a group of pupils comes up to you: 'We're going to the Albert Heijn, are you coming?' What do you say then?" "No", says Erhan. "Very good" replies the policeman "that's the only right answer." The policeman raises the classroom tension further, and now talks about boys who sneak past the cash register and are then arrested and sentenced to four months' juvenile detention. He links the behaviour of these boys to 'bullying'. "I know for a fact that the boys who are now criminals were actually all bullied in the past." He then asks, "Which of you has been bullied in the past? And which of you is brave enough to talk about it?" Several children raise their hands. Erhan tells: "I was with other kids, and they bullied us. They grabbed us in the neck and held us down [...]. A few days later we were bullied again by the same group [...] And after that it began to happen more often." The neighbourhood policeman sees Erhan wringing his hands and says in an empathetic tone, "That hurts, doesn't it?" "Yeah, it really does," Erhan continues "because I have two grandmas at home, and one of my grannies died of cancer, and they say 'cancer granny'." "I got her name too", he adds. "Oh, lad," replies the neighbourhood policeman and puts his arm around Erhan, and tears start to roll down Erhan's cheeks.

\subsection{Hidden Tears}

No tears are visible on Gianny's face when his mother gets up and walks away from the mentoring session. The reason for the talk with Gianny and his mother is that Gianny has been suspended. He has "given another pupil a couple of headbutts." Even if someone makes racist remarks to you, the mentor says, "you can obviously not use violence at school." In general, things are not going well for Gianny at school: "Your grades are not good, your motivation is not good." Mother adds: "Things are not going well at school, and you've caused that mess yourself. When you do something, you immediately have a problem. When other children do something, they're given another chance. They don't joke with you anymore [...]. Here at school, they're fed up with you as well." And mother leaves the conversation. Gianny stays behind, feeling hurt. His tears are hidden behind his silence.

\subsection{Being Vulnerable Isn't Tough}

"I've just had a phone call, about Gianny. He's in jail," teacher Thijs hears one morning, before class begins. This is not the first time - "another robbery." "We can't hold his hand all day," sighs Thijs when he talks to the principal about it, "that's what the mother says too, she's upset as well and she doesn't know what to do about it either." Teacher Thijs is in favour of acting 'as normal as possible' towards Gianny at school. All of them know that Gianny will tell his classmates about it at school, and "it does increase his status of course. It confirms his villain status here 
at school." And indeed, Gianny is welcomed as a hero by his classmates. He proudly says that he was caught redhanded. "It was that new blue van" in which he was taken to the station, he tells - hiding his vulnerability behind his tough attitude.

\subsection{Vulnerability as Object of Reflection}

It takes a lot of work to keep Gianny off the streets. Eventually, he is placed in a residential group. His new daily rhythm consists in being transported by taxi from this residential group to school, from school to his social daytime activities, and from these daytime activities back to the residential group. In this living group - in adaption to these times of Corona - he receives help with his online schoolwork. Together with a social worker, he reflects on how he is doing right now, and has made the discovery that it helps to put 'pain and stuff' on paper in a 'different kind of music': 'spoken words' (rap music). When asked whether he can share his feelings in any other way, or with anyone else, apart from putting them on paper, he answers after a long silence: "With no one really." By using the metaphor of the 'overflowing bucket', the social worker teaches Gianny to talk about his pain and grief. "You know the thing with me," says Gianny, "is that whenever someone makes me angry or something, I just leave it be. But at some point it just gets too much [...]. In the residential group 'Eigen Kracht' ('My Own Strength') it's not the law of the tyranny of the street that rules, which makes it impossible for you "to forge your own path." "Here it's simply a place of brotherhood [...] and when I'm at a school with kids who see a future for themselves and stuff, then I can choose a path myself and choose who I want to flow with."

\section{Teacher Maria - Narrated Vulnerability as an Inner Voice}

Maria, a native Dutch religious/worldview education teacher, tells of the moment when she felt like the ground gave way under her feet and she was left speechless. Her students are girls who are being trained to become assistants in Mental Health Care, Disability Care, Nursing and Care Facilities and Home Care, or in Maternity Care. Taking into account their future workplaces, and starting from the intercultural and interreligious diversity of the people they would come into contact with there, Maria had decided to dedicate her lesson to 'religious diversity'. "I made a nice PowerPoint, found a suitable video on YouTube to go with it, prepared a nice form of formative testing, in short: as far as I was concerned, I was well prepared." However, the girls had a different idea about being together, at that moment, in this classroom. They are having a nice chat with each other. "Even when the first slide came up, nothing happened, at least not with the class, but something started happening to me. I cleared my throat, tried to raise my voice above the chatter of the girls. It didn't really work, or rather: it didn't work at all. I tried again, in a slightly louder tone. No result. I tapped the table to rouse their attention. Still no reaction. I raised my voice. That resulted in one of the girls slowly turning around, facing me and saying: 'We are talking, Miss, can't you see that?!' I felt so vulnerable, with what happened to me then...".

\section{I The Feeling of Not Being Recognised}

Maria continues: “With a shock, what is happening with the girls in the classroom triggers a memory - I'm back in group 8 of my own primary school. On that day, our teacher was ill and a substitute teacher would arrive that morning. We could go straight to our classroom, and we had already started - as our teacher called it, and always did at the beginning of the day - 'to go through the events of our lives.' Then the new teacher entered. She began to explain her class rules and we immediately had to get out our math books. We were stunned. We were used to sharing the things that preoccupied us with each other and with the teacher! Didn't she want to know who we were? The feeling of not being recognised..."

In a split of a second, this memory of her emotions back then brings Maria back to the question of one of the girls: "We are talking, Miss, can't you see that?!" She suddenly knows what she has to do. It is obvious to her that she has to start a conversation with these students, and she asks the girl in question: "Can we continue that conversation together? I don't even know your name," and to the class: "I don't know any of your names. I don't really know who I have in front of me, and you don't know who I am. Shall we start with that first?"

For Maria, 'the feeling of not being recognised' is the trigger for a completely different approach to her pupils. In the preparation of this lesson, she did have the group of pupils in mind, but only from the perspective of their future work situation. Because she worried about seeming uninformed, possibly because she herself had little experience with people from other cultures or religions, Maria had prepared her lesson very well. Initially, she reacted tensely to the pupils' disinterest. Fortunately - both for her and the pupils - Maria could draw strength from her 
woundedness as an eighth-grader to open up to her pupils, and to ask them to let themselves be known. She lets go of her preparation and improvises a lesson on 'getting to know each other.'

\section{Vulnerable Religion - A Serious Game}

Maria drops her plan to devote her lesson to 'religious diversity' and instead begins her lesson with a conversation, which strikes her as obvious at that time. There is little that is 'obvious' in the post-modern society - everything has become fluid. The obviousness of religion, or even the plausibility of religion, is under discussion in post-modern society as well, observes the theologian Jan Marten Praamsma (2020). According to him, the vulnerability of religion lies in the tension between the game element of religion and the rules that govern it, and 'what is at stake in religion.' Praamsma refers to the historian and cultural philosopher Johan Huizinga, who states that what is characteristic of games is that they have rules that are only valid within the game itself. Think, for example, of the rules of the game in various sports. You can look at religion in the same way - as a game that is played in accordance with the rules of that game, with all the attributes that are necessary to be able to play the religious game - including the big book containing all the rules. Some, accordingly, view modern-day sports and their rules as a new form of religion (for players as well as for the public) (Ganzevoort, 2006). Others stress the meaning- and sense-giving aspect of religion, and, rather than speaking of the concept of 'religion' that is under societal pressure these days, prefer to speak of 'worldview' (Selçuk \& Valk, 2012) or 'life orientation' (Van der Zande, 2018). Still others draw attention to people's interaction with what is empirically unobservable, the so-called 'trans-empirical' (Praamsma, 2020). What would be at stake here is a part of reality that is not discernible to the naked eye, of which we nevertheless suspect the existence. When it comes to religion, different things are at stake for different sorts of people.

Although religion has a game-like character, it is at the same time a very serious matter. For those engaging with it, religion is all about existential matters, revolving around such questions as those about infinity, finitude and the boundaries of existence; questions about responsibility, freedom, guilt and failure; questions about the good, happiness, peace, meaning, well-being and prosperity; the question about the receiving of insight and, last but not least, questions about evil and the suffering that occurs in the world (Vroom, 1988; Visser-Vogel, 2018). These are very fundamental questions; religion is not a side-issue but a matter of the head, heart and hands in the lives of religious peo-ple. There is much at stake.

Religions, those are: people, who pass on stories and myths to each other, in rituals and symbols, about the fields of tension that human beings have in the past experienced - and continue to experience - in their positioning with regard to the ground of existence, in their dealings with 'good' and 'evil'. Stories about consolation, liberation and hope; stories as answers to life's great questions; dreams that things will work out in the end in the form of images that go beyond the boundaries of this reality. This is what religions express with the concept of 'transcendence'.

Religions make themselves vulnerable when they claim to possess the complete truth, or also when they - in their own literal understanding of the holy texts and their ultimate responses to life's great questions - turn their backs to these world-transcending, hope-filled images. Instead, this everyday transcendence of ordinary people is one to which they should be referring, according to Praamsma (cf. Tish Harrison Warren's Liturgy of the Ordinary, 2016). "It is precisely in this referring to transcendence that religion turns out to be a serious matter." And he continues, building on Huizinga: "Religion has the various characteristics of a game, but it is certainly not just a frivolous game to pass the time." The relationship between 'game' and 'seriousness' is complex - "On the one hand, there is the game with its own rules, which is self-sufficient, and on the other hand, there is the seriousness of answers to the big questions of life itself." What we are dealing with here are hope-filled images about a world in which every person experiences that they are being recognised and valued for who they are. Images that affect us. Images that motivate us to act. Images that invite vulnerability.

\section{From Vulnerability to Strength}

This contribution started with the question: "How do we understand 'vulnerability' and in what way can vulnerability be part of a pedagogical strategy?" To answer the first part of this question I began by taking a closer look at the concept of vulnerability. Gustavsson (who builds on the work of Brené Brown) drew our attention to different aspects of vulnerability by distinguishing between experienced vulnerability, narrated vulnerability and induced vulnerability. These three aspects of vulnerability were recognised in educational settings: the documentary 'Classrooms' and the narrative of a teacher. Experienced vulnerability is a type of vulnerability that exists within the moment itself. In the documentary 'Classrooms', Erhan's vulnerability is visible when he talks about his grandmother 
who passed away, the grandmother who gave him his name. Narrated vulnerability is vulnerability as object of reflection. Close-reading the story of teacher Maria we learn about narrated vulnerability. Maria draws upon a personal memory through which she re-tells herself, as it were, how vulnerable she felt in the 8th grade when she felt she was not being recognised. This form of vulnerability motivates her and gives her the strength to begin a conversation with her students. Induced vulnerability is a type of vulnerability that is caused by someone else; something that happens to you. In the documentary 'Classrooms', in the meeting that Gianny and his mother have with a mentor, Gianny's mother induces Gianny's feelings of vulnerability when she abruptly leaves the mentoring session.

The examples above show, in line with Brown's and Gustavsson's lines of thought, that vulnerability is a two-sided phenomenon. Pupils who were invited to write about their experiences not only tell about their feelings of vulnerability as feelings of weakness, but also write about the strength that can be gained when experienced vulnerability is shared. The love received from family and friends turns vulnerability into strength. 'The other' facilitates the transformation of experienced vulnerability into narrated vulnerability. It is in this way that Erhan is strengthened in his story by the arm of the neighbourhood policeman around his shoulder, creating space for Erhan's tears. Tears that express his vulnerability, which is recognised and even welcomed by the arm around his shoulder, accompanied by the policeman's words “That's brave! That's frightening, isn't it, that sadness! That's brave of you that you've got the courage to tell this."

Experienced vulnerability is coined as 'brave' - a first step on the way to narrated vulnerability? Teacher Maria relies on a 'voice' in her inner self, and gains strength by turning her own woundedness around, in making the effort to get to know her pupils; an example of the beautiful risk of education in the sense of a practice that requires time, is unpredictable, and of which the outcomes are uncertain (Biesta, 2014). Narrated vulnerability becomes part of teacher Maria's pedagogical strategy. People derive strength from each other, from each other's stories, dreams and hopes; which is an external strength that transforms into an inner strength - a new inner 'voice' is being dialogically added to the 'multiple-voiced self' (Hermans \& Hermans-Jansen, 1995). From the examples presented above, I conclude that the development of narrated vulnerability can be stimulated in a natural way at unexpected moments, in informal encounters between family members, friends and classmates. The second part of my question, "in what way can vulnerability be part of a pedagogical strategy?," can be answered in the following way: vulnerability as a processed experience, as narrated vulnerability, can be part of a pedagogical strategy that is effective at (un)expected moments in formal educational settings.

\section{I Vulnerable People Meet Vulnerable Religion}

The Dutch rapper Typhoon (2020) finds words to express his dream in his Christmas poem. He concludes his dream - which motivates him and gives him the strength to act - in the following way:
A longer look at each other
will make us meet
receptivity over reason.
The benefit of the doubt
is the precursor of peace.

The young writer Marieke Lucas Rijneveld (2021) dreams herself out of the current Corona time ("imagine yourself outside, feel the wind through your hair, the rain, imagine summer at your side"). Amanda Gorman (2020) does the same in her speech during the inauguration of Joe Biden. Her spoken word poem 'The Hill We Climb' ends with the words:

The new dawn blooms as we free it

For there is always light

If only we're brave enough to see it

If only we're brave enough to be it.

How beautiful would it be if the stories, the dreams and the hopes of vulnerable young people could be found and recognised in the stories told by vulnerable religions. When the lightness of the religious game would encourage us to put our vulnerability on the line (Brown, 2010). In doing so, we would make true what one of the pupils writes, that we become more beautiful people when we have the courage to share our vulnerability.

This is not easy - becoming a more beautiful human being by sharing your experienced, narrated and induced vulnerability. Sharing it not only with family members, classmates, and friends, but also precisely in the encounter 
with the wisdom found in religious traditions. Not with a wisdom carved in stone as a collection of answers to life's great questions, but with a living wisdom that, growing through the centuries, remains deeply connected with people of flesh and blood. In dialogue with traditions, experienced vulnerability may turn into narrated vulnerability; a process of learning from traditions, of learning to enter into narrated vulnerability as a constructive power in formal and informal encounters in education. More research is needed on the possible developmental aspects of Gustavsson's types of vulnerability, and their interrelatedness with other personal characteristics. Based on further research into Brown's and Gustavsson's conceptualisations, the implementation of these kinds of research results in teacher training needs to be addressed. What we do know, though, is that sharing one's vulnerability requires first of all a safe space - for all persons involved - in order to create room for an authentic eagerness, paired with a will to get to know the 'other' (who is near, far away, or found in stories) and - finally - enriched with the will to let yourself to be known. A will to open oneself and to become 'known others'.

None of this is easy - not for pupils, not for teachers. It takes courage, but "let us shoulder together the reality that the end point is not known, but that we can get there together" (Van Hintum, 2021).

\section{Bibliography}

Biesta, Gert J. J. (2014). The Beautiful Risk of Education. London: Paradigm Publishers.

Brown, Brené (2010). The Gifts of Imperfection: Let Go of Who You Think You're Supposed to Be and Embrace Who You Are. Center City: Hazelden.

Brown, Brené (2012). Daring Greatly. How the Courage to Be Vulnerable Transforms the Way We Live, Love, Parent, and Lead. New York: Penguin.

Ganzevoort, Reinder (2006). De hand van God en andere verhalen. Over veelkleurige vroomheid en botsende beelden [The Hand of God and Other Stories. On Multicoloured Piety and Colliding Worldviews]. Zoetermeer: Meinema.

Gorman, Amanda (2020). The Hill We Climb. Poem recited during the inauguration of Joe Biden as the 46th President of the United States.

Gustavsson, Caroline (2020a). Vulnerability as a Quality in the Classroom and Research in Religious Education. In Ina ter Avest, Cok Bakker, Julia Ipgrave, Silke Leonhard \& Peter Schreiner (Eds.), Facing the Unknown Future. Religion and Education on the Move (pp. 183-194). Münster: Waxmann.

Gustavsson, Caroline (2020b). Kwetsbaarheid als kwaliteit [Vulnerability as a Quality]. Narthex, 20(4), 35-40.

Hermans, Hubert J. M. \& Hermans-Jansen, Els (1995). Self-Narratives. The Construction of Meaning in Psychotherapy. New York: The Guilford Press.

Praamsma, Jan M. (2020). Kwetsbare religie voor kwetsbare mensen. Over ernst en spel in de wereld van geloof en religie [Vulnerable Religion for Vulnerable People. About Seriousness and Games in the World of Faith and Religion]. Narthex, 20(4), 7-14.

Rijneveld, Marieke L. (23. Januar 2021). Avondklok [Curfew]. Daily Newspaper Trouw.

Selçuk, Mualla, \& Valk, John (2012). Knowing Self and Others: A Worldview Model for Religious Education in Turkey. Religious Education: The Official Journal of the Religious Education Association, 107(5), 443-454.

Sylbing, Sarah \& Gould, Ester (Directors \& Producers) (2020). Klassen [Classrooms] [Documentary series]. Amsterdam: HUMAN. Retrieved from https://www.npostart.nl/klassen/VPWON 1304701 [28.01.2021]

Typhoon (23. Dezember 2020). Kerstgedicht [Christmas Poem]. Daily Newspaper Trouw.

Van der Zande, Edwin (2018). Life Orientation for Professionals. A Narrative Inquiry into Morality and Dialogical Competency in Professionalisation (PhD Study), Utrecht University, Utrecht.

Van Hintum, Malou (23. Januar 2021). Mensen zijn ingewikkeld, dus stap af van de labels in de GGZ [People are complicated, so stop labelling in Mental Health Care]. Interview with prof. Floortje Scheepers, Daily Newspaper Trouw.

Visser-Vogel, Elsbeth (2018). Religious identity development of orthoprax Muslim adolescents in the Netherlands (PhD Study, Utrecht University). Enschede: Gildeprint.

Vroom, Henk (1988). Religie als ziel van cultuur. Religieus pluralisme als uitdaging [Religion as the soul of culture. Religious pluralism as a challenge]. Zoetermeer: Meinema.

Warren, Tish H. (2016). Liturgy of the Ordinary: Sacred Practices in Everyday Life. Westmont: InterVarsity Press. 